G. Gahramanov, Cand. Sci. (Geol.), E-mail: gngahramanov@gmail.com, State Oil Company of Azerbaijan Republic (SOCAR), Baku, Azerbaijan;

M. Babayev, Cand. Sci. (Geol.), E-mail:m.s.babayev@mail.ru, Azerbaijan State University of Oil and Industry, Baku, Azerbaijan;

S. Shpyrko, Cand. Sci. (Phys.-Mat.), E-mail: sshpyrko@gmail.com,

Department of Marine Geology, National Academy of Sciences, Kyiv, Ukraine;

Kh. Mukhtarova, Cand. Sci. (Geol.),

E-mail: mukhtarova.khuraman@mail.ru,

Azerbaijan State University of Oil and Industry, Baku, Azerbaijan

\title{
SUBSIDENCE HISTORY AND HYDROCARBON MIGRATION MODELING IN SOUTH CASPIAN BASIN
}

\begin{abstract}
(Представлено членом редакційної колегї д-ром геол. наук, проф. О.М. Карпенком та канд. геол. наук, доц. А.П. Тищенком) We study the mechanisms of migration and spacial distribution of hydrocarbon deposits along a regional $1000 \mathrm{~km}$ long SW - NE seismic cross section of the South Caspian Basin. A retrospective $2 D$ geological simulation of basin subsidence and sediment filling history is performed taking into account accompanying processes of thermal and catagenetic transformations of organic matter, and subsequent migration and accumulation of hydrocarbons.

The start of the basin opening with accumulation of considerable sedimentary mass can be dated as middle Mesozoic (Triassic or Jurassic), and hydrocarbon prone horizons can now be located at depths of $12 \mathrm{~km}$. The hydrocarbon saturation of the Pliocene Productive Series is of epigenetic (allochtonous) nature, which is also confirmed in literature by geochemical data from mud volcanoes and by other facts. Geochemical age, depth of provenance and reworking degree of hydrocarbons point at generation sources in Mesozoic (gas) and Paleogene-Miocene formations (oil) with only subordinate participation of the lower "Productive Series" Pliocene suites. The dominant migration pattern of fluids is interformational (interstratal) intermittent injective subvertical flow along disjunctive planes, zones of increased fracturing and loose rocks, diapir intrusion contacts, eruptives of mud volcanoes, lithofacial unconformities and other structures, breaking the rocks continuity. This implies the possibility of commercial-scale accumulations of hydrocarbons at ultra high depths, if trap structures of sufficiently large sizes are available, comparable with already discovered giant oil and gas fields (Shah-Deniz, Azeri-Chirag-Gyuneshli etc).
\end{abstract}

Keywords: hydrocarbon migration, sedimentary basin modeling, backstripping, deep hydrocarbon potential, PETROMOD

Introduction. The South Caspian Basin (SCB) with up to $15-25 \mathrm{~km}$ thick sediment cover, especially in its central parts, belongs to the deepest sedimentary basins of the world. According to modern views, this is a backarc basin of Tertiary age, closely related to Alpine orogenesis (Zonenshain and Le Pichon, 1986; Khain et al., 2009). These values of sediment thickness are confirmed mostly by gravimetry and seismic surveys (Brunet et al., 2003). Characteristic features of SCB are avalanche sedimentation, extremely high subsidence rate during Pliocene and Quaternary, and anomally low subsurface temperatures (Smith-Rouch, 2006; Kerimov et al., 2010; Rachinkiy and Kerimov, 2015). This basin is one of the world oldest oil exploration regions with unique oil and gas reserves (proven reserves above 20 bln barrels of oil equivalent (Abrams and Narimanov, 1997; Smith-Rouch, 2006; Klett et al., 2010).

Most oil bearing and prospective Azerbaijan regions feature two hydrocarbon layers, of Pliocene and Mesozoic age, respectively (Khain, 2005), separated by a thick Paleogene-Miocene clayish formation. The lower $\mathrm{HC}$ level in SCB is generally traced down to depths of ca. $6.5 \mathrm{~km}$ in Upper Mesozoic and Lower Cenozoic sediments (Guliyev et al., 2003). Cenozoic layers are essentially better explored, and most basin simulation projects deal with these horizons (depths to 2-3 km). The most explorable HC-generating layer is the Maykop suite (Oligocene) and its overlying "Productive Series" (Smith-Rouch, 2006; Vincent et al., 2010; Bonini et al., 2013), which consists of Pliocene sequences of varying lithology. The lower (Mesozoic) HC layer is more complicated structurally, with multiple sedimentation breaks and structural unconformities. Mesozoic oil in Azerbaijan is still an unresolved challenge. Exploration works nowadays tend at Mesozoic $\mathrm{HC}$ prospecting (Guliyev et al., 2009). However, drilled wellbores mostly pierce in Cenozoic sediments, they rarely reach Upper Cretaceous strata. Information about the underlying Mesozoic (Triassic and Jurassic) suites originates from geophysical interpretations and simulations (Glumov et al., 2004; Artyushkov, 2007; Golonka, 2007; Piip et al., 2012; Rachinskiy and Kerimov, 2015). Even more hypothetic are inferences about possible underlying Paleozoic layers, especially in view of the discussions about the opening time of SCB (Berberian, 1983; Zonenshain and Le Pichon, 1986; Abrams and Narimanov, 1997; Brunet et al., 2003; Khain, 2005; Artyushkov, 2007; Golonka, 2007). The unique Shah-Deniz gas condensate field has been recently discovered at a depth of ca. $7 \mathrm{~km}$ in SCB. Similar deeplaying oil and gas fields are known worldwide. The discovery of major $\mathrm{HC}$ fields at ultra high depths poses the challenge of exploring the structures and $\mathrm{HC}$ bearing capacities at these depths, where common horizontal layered models for shallow intervals appear inadequate.

There are two competitive views on the origin, migration and accumulation of oil and gas in the area. The supporters of the syngenetic origin of hydrocarbons argue that the bulk of deposits was formed by a lateral migration of fluids from the central part of the basin to its periphery (Yusifov and Rabinowitz, 2014; Javanshir et al., 2015). Others support rather secondary, or allochtonous HC saturation mechanisms in the mid-Pliocene suites of Productive Series in the western and southern parts of the basin (Inan et al., 1997; Feyzullayev, 2013a). According to this view, most hydrocarbons migrated from deep-seated underlying Paleogene-Miocene and Mesozoic strata through a system of penetrating faults, zones of contact of diapir intrusions with adjacent reservoirs, mud volcanoes eruptives etc. during periods of tectonic activation. A promising field of research in favor of this concept would be mud volcanoes and their relation (apparent, yet still unclear) with $\mathrm{HC}$ sources distribution (Huseynov and Guliyev, 2004; Yusifov and Rabinowitz, 2004; Feyzullayev, 2012; Bonini et al., 2013). The supporters of this concept, however, admit the generation of certain amount of $\mathrm{HC}$ from the Productive Series in some areas of SCB.

Subsidence simulations and modeling in SCB region are abundant (Inan et al., 1997; Tagiyev et al., 1997; Brunet et al., 2003; Artyushkov, 2007; Green et al., 2009; Abdullayev et al., 
2015; Kerimov et al., 2015; Rachinskiy and Kerimov, 2015; Guliyev et al., 2017). Many authors conclude about the basin initiation during Mesozoic, often relating it to the rift opening in Later Jurassic (Abdullayev et al., 2015). However, there are indications, in particular, 1D modeling on wellbores, that trace back the recorded stages of tectonic subsidence to earlier epochs, including Late Devonian (Brunet et al., 2003). Such data are obtained in Alborz (Iran), southern part of SCB. Studies of thermal conditions over multiple wellbores show, that this is a cold basin compared to similar fields worldwide. Low subsurface temperatures and geothermal gradients are a consequence of the avalanche sedimentation. As a result, rocks below $6 \mathrm{~km}$ can still remain suitably cold to reside within the oil or gas generation window. Together with indications of possible early formation (basin as a whole or its parts), this can favor the conclusion about $\mathrm{HC}$ producibility zone in SCB stretching essentially below the deemed $6,5 \mathrm{~km}$ limit, and reaching $10-15 \mathrm{~km}$. The discovery of such fields at ultra high depths is probable in young basins with rapid sedimentation (10-15 MA old) (Kerimov et al., 2015), which is the exact case of SCB at its modern stage. Therefore, justification of the lower boundary of $\mathrm{HC}$ distribution in this sedimentary basin is of primary importance. Confirmation of this assumption gives additional arguments in favor of the secondary (allochtonous) HC saturation of the Productive Series, hence, allows refining local migration models as well.

To examine this, regional 2D modeling was performed (Welte et al., 2000; Makhous and Galushkin, 2005; Kauerauf and Hantschel, 2009) along several interpreted seismic profiles. The principal attention is paid here to the results along a ca. $1000 \mathrm{~km}$ profile with SW-NE trending, crossing major regional tectonic structures in the direction of assumed tectonic flow at Tethys closure and collision of Arabian and Eurasian plates. The $\mathrm{HC}$ migration and accumulation modeling was also performed along the profiles for several temporal snapshots, including the moment of Pliocene Productive Series formation and present time.

The aim of the work is the study of $\mathrm{HC}$ generation, migration, accumulation mechanisms and their spatial distribution along a section of the SCB depression. Section 2 , continuing the Introduction, presents general knowledge of the geology, lithology and stratigraphy of SCB sediments. Principal $\mathrm{HC}$ generating suites are briefly described. A short reference is given of the local stratigraphic nomenclature, mostly for Neogene suites (Productive Series). In Section 3, the computer modeling of the basin paleoreconstruction, and $\mathrm{HC}$ migration and accumulation in PETROMOD software is described. Section 4 presents the modeling results for the Basin paleohistory and $\mathrm{HC}$ distribution along a regional profile and locally (as case study of a giant field). Section 5 and Conclusion present the results as compared to other simulations and empirical wellbore data; possible reasons for inconsistencies and ways of future model improvements are discussed. General conclusions on the deep HC potential are drawn and future researches are outlined.

Materials and methods: Geological settings. Caspian region is a structure with complicated geology and tectonics, featuring the conjugation of continental structures with different ages: East European (pre-Cambrian) platform, Skythian-Turanian platform and Alpine fold systems on the South. Three major geological units are distinguished: North Caspian, Middle Caspian and South Caspian (Guliyev et al., 2003; Glumov et al., 2004; Khain et al., 2009; Rachinskiy and Kerimov, 2015). The South Caspian depression is a tectonic structure within Alpine-Himalayan mobile belt. Modern tectonic setting of the South Caspian depression is bound to the southern Caspian Sea and adjacent onshore zones of Eastern Azerbaijan, Western Turkmenistan and Northern Iran (Figure 1).

The prevailing point of view assumes the origin of SCB as a post-rift basin with underlying (sub-)oceanic crust (without a granite layer), featuring abnormally high subsidence and avalanche sedimentation in Upper Neogene-Holocene. Indicative sedimentation rate for Mesozoic cycle is $40-90 \mathrm{~m} / \mathrm{MA}$ (meters per million years), for Paleogene-Miocene: $35-80 \mathrm{~m} / \mathrm{MA}$, and for PlioceneHolocene: 350-900 m/MA (Glumov et al., 2004; Kerimov et al., 2015). The average thickness of the sedimentary cover varies from $7-8 \mathrm{~km}$ to $28-30 \mathrm{~km}$, reaching maximum in the most subsided offshore parts of the South Absheron depression and Baku Archipelago. Three formation layers are distinguished, strongly differentiated by their lithofacial composition (Aliyev and Aliyev, 2011):

1) Meso-Cenozoic terrigene and carbonate formation (Lower and Middle Jurassic to Upper Cretaceous, 4-11 km thick); 2) Paleogene-Miocene, predominantly clayish, comprising Danian and Pontian (2,5-5,5 km); and 3) Pliocene-Holocene, interleaved sand and clay facies with thickness of 6-7 km.

The synthetic stratigraphic column in Fig. 2 summarizes the geology of Miocene-Pliocene reservoir and source rocks. The prospective Productive (or Redstone) Series is composed of clastic terrigene material. Its nine suites are clearly separated into two groups, divided by the Break (or Fasila) Suite. The lower group is dominated by Quartz in clastic sediments, and traced to the Paleo-Volga riverwash. The upper group contains less Quartz compared to feldspar etc, and clastic fragments relate to sedimentary and volcanic rocks with provenance from Paleo-Kura river (Abrams et al., 1997; Vincent et al., 2010). The underlying Maykop suite (top Oligocene - lower Miocene) is an important regional source rock horizon with analogs of the same age stretching up to Carpathians. It is composed of dark clayish rocks with abundant organics and sedimentation in anoxic environment. To a lesser extent, the Diatom suite above Maykop is also considered as a HC source rock (SmithRouch, 2006; Javanshir et al., 2015).

Within SCB, several separated generation foci of $\mathrm{HC}$ can be revealed in different Mesozoic-Cenozoic strata. Five $\mathrm{HC}$ generation intervals are distinguished: two Mesozoic (middle Jurassic, lower Cretaceous), Paleogene - Upper Miocene (mostly Maykop), Middle and Upper Miocene (Diatom) and Lower Pliocene (Kalinsk suite in the lower part of the Productive Series) (Guliyev et al., 2001, b; Guliyev et al., 2003).

The upper formations (Productive Series) are composed of extended contiguous permeable layers, capable of lateral fluid migration, that is they correspond to the custom horizontal layered reservoir concept. However, deep horizons feature block and block-layered structure (Guliyev et al., 2017). In SCB, these depths are Paleogene-Miocene and Mesozoic strata. As a consequence, there are no favorable conditions for regional migration flows. A new type of hydrodynamical systems with intermittent (pulsation) injection dominates there, covering important ranges of deposits and characterized by large-scale distribution of vertical interformational flows over networks of high amplitude faults (Feyzullayev, 2012). Deep fluids are unloaded predominantly vertically. During tectonic activation periods, the mixtures of gases and fluids can disrupt the layers of the sedimentary cover and form interlayer intrusions, and even reach the surface as mud volcanoes (Yusifov and Rabinowitz, 2004; Davies and Stewart, 2005; Feyzullayev, 2012; Guliyev et al., 2017). These particular features at ultra high depths are crucial for modeling and assessing of the HC potential of deep subsidence basins. 


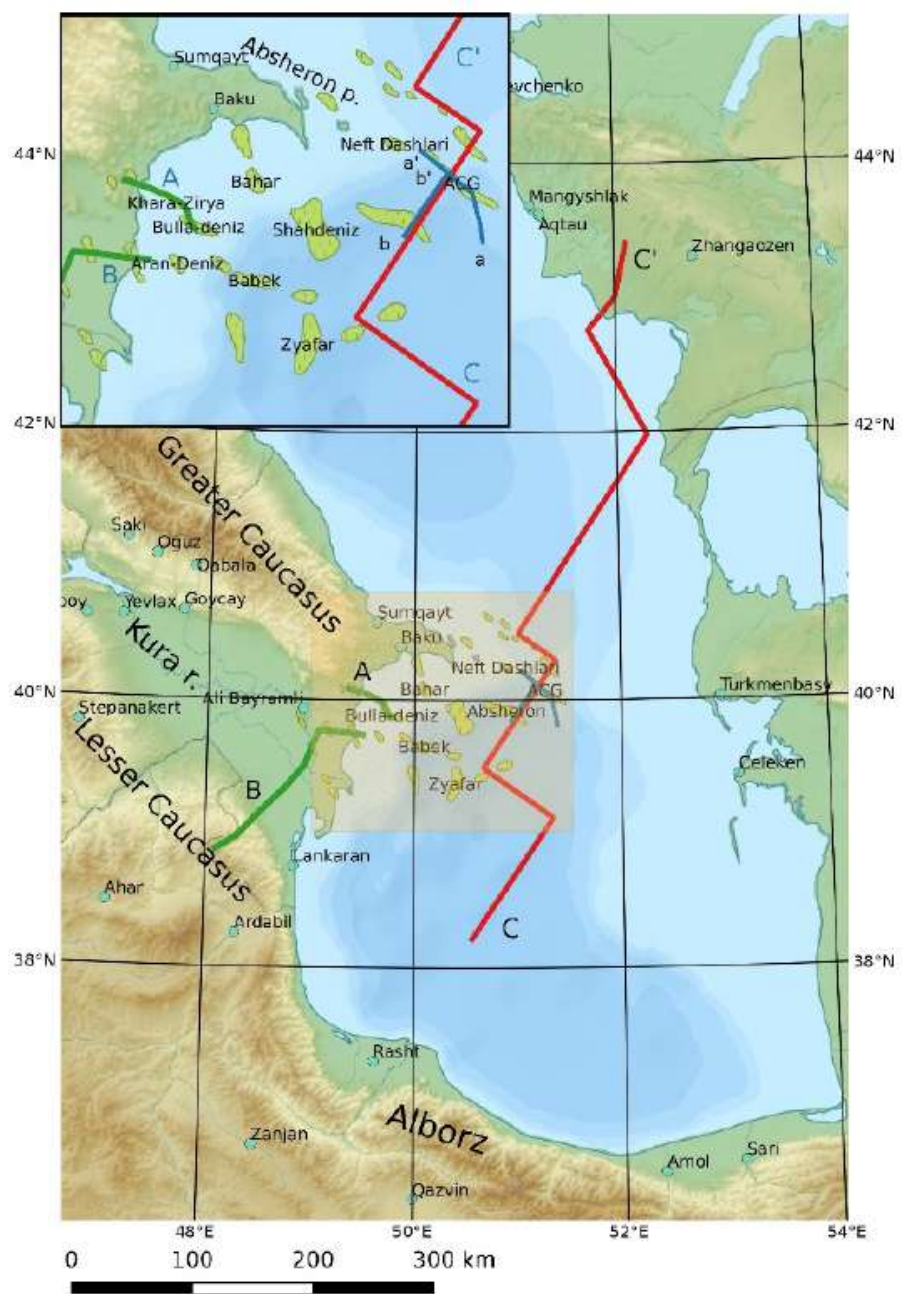

Fig. 1. General layout of SCB, modeling profiles and major oil\&gas fields. Red line (C-C'):

regional SW - NE profile, Figs. 4, 5; blue lines (inset, a-a', b-b'): profiles used in local migration model of ACG field, Fig.6, a, b

Principles of geological modeling in SCB. The key technique for the exploration of the deep structure of SCB is the basin simulation (Makhous and Galushkin, 2005; Kauerauf and Hantschel, 2009), referenced to the modern geological setting and certain independent indicators (e.g., location and composition of mud volcanoes, sedimentation data and geochemical logging in ultradeep wellbores).

The computer simulation of the sedimentation history and $\mathrm{HC}$ distribution at several time marks in SCB was performed with PETROMOD (2D modeling over several interpreted seismic sections). Most known 2D modeling packages can also simulate fluid flow rates in $(X, Z)$ plane. PETROMOD package can simulate three-phase displacement (system of oil+gas+water), secondary migration and accumulation of hydrocarbons. The distribution of $\mathrm{HC}$ saturated solution over section is calculated from the application of Darcy law taking into account capillary pressure, or with a hybrid FlowPath technique (Welte, 2000). The cycle of 2D simulation runs was designed for two groups of problems: 1) sedimentation modeling over geological past (diachrony) and 2) $\mathrm{HC}$ migration and distribution modeling over relatively short time scale (for example, for the Productive Series deposition).

The regional SW-NE trending profile for PETROMOD 2D simulation, about $1000 \mathrm{~km}$ long, is shown as $\mathrm{C}-\mathrm{C}^{\prime}$ line in Fig. 1. It crosses Pre-Alborz, Lower Kura, South Absheron depressions. The modeling of $\mathrm{HC}$ migration and accumulation was also performed over other seismic sections at smaller scale, in particular, across oil structures Kyanizadag, Sangachal, Duvanny, Harya-Zirya and Bulla-Deniz (line A,
Fig. 1), and southwards, along the line B in the South Kura depression (see Fig. 1). These smaller profiles were chosen to cover large onshore and offshore fields with general direction across dominating trends of tectonic structures. We give here representative results mostly for the region-wide $\mathrm{C}-\mathrm{C}^{\prime}$ profile, which crosses main Caspian structures from pre-Alborz depression towards Turan plate.

\begin{tabular}{|c|c|c|c|c|}
\hline \multicolumn{2}{|r|}{ Epoch } & Age & Suite & Lithology \\
\hline \multicolumn{2}{|c|}{$\begin{array}{l}\text { Holocene } \\
\text { Pleistocene }\end{array}$} & & $\begin{array}{c}\text { Baku } \\
\text { Absheron }\end{array}$ & \\
\hline & \multirow[t]{2}{*}{ Upper } & \multirow{4}{*}{ 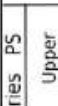 } & Surakhany & \\
\hline & & & Sabunchy & \\
\hline & \multirow{3}{*}{ Middle } & & Balakhany & $\cdots$ \\
\hline & & & Fasila & 1 \\
\hline & & \multirow{4}{*}{ | } & $\begin{array}{l}\text { Nadkirmaky cl, NKG } \\
\text { Nadkirmaky sand NKP }\end{array}$ & \\
\hline \multicolumn{2}{|r|}{ Lower } & & Kirmaky KS & \\
\hline \multirow{4}{*}{ 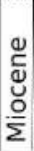 } & & & Podkirmaky PK & \\
\hline & & & Kalinsk KaS & \\
\hline & & & Pont, Meot., Sarmat. & \\
\hline & & & Diatom & \\
\hline \multicolumn{2}{|c|}{ Oligocene } & \multicolumn{2}{|c|}{ Maykop suite } & \\
\hline \multirow{2}{*}{\multicolumn{2}{|c|}{$\begin{array}{l}\text { Eocene } \\
\text { Paleocene }\end{array}$}} & & & \\
\hline & & & & \\
\hline \multicolumn{4}{|c|}{ Cretaceous } & \\
\hline
\end{tabular}

Fig. 2. Synthetic local stratigraphic chart of SCB Neogene. Lithology is schematically denoted by dots (sandstone reservoirs), hatches (clay seals) and by wavy hatching (source rocks) 
Principal parameters for the input of the basin reconstruction simulations include: 1 ) initial state (geological cross section at present time); 2) temperature-depth dependence, including assumptions about its evolution in the past; 3 ) sedimentation and subsidence rates for different geological ages; 4) assumed reconstructions of the thickness change due to horizontal tectonic movement (backstripping) (Makhous and Galushkin, 2005; Mustayev, 2013; Kerimov et al., 2015).

We took interpreted geological sections from 2D seismic as input data (starting point for backward modeling). The initial cross section for the "main" regional profile C-C' in Fig. 1 is given, for example, in (Glumov et al., 2004). Similarly, recent interpreted 2D seismic data was used for runs over other profiles.

Temperature is the principal factor of conversion of the organics into hydrocarbons. Thermal regime of a basin with its assumed evolution over time is a key input into modeling programs. For SCB, over 4,500 measurements of formation temperatures are available for depths over $5000 \mathrm{~m}$ (Tagiyev et al., 1997; Guliyev et al., 2003; Guliyev et al., 2009; Rachinskiy and Kerimov, 2015). Generalized temperaturedepth curves for SCB and similar giant world basins are given for reference in Figure 3. For a brief outline of the geothermal conditions in SCB, see (Gahramanov et al., 2019). The principal feature of SCB is its anomalously low heating of Pliocene and Quaternary strata, which makes it one of the "coldest" world basins. Such environment implies the possibility for $\mathrm{HC}$ generation even for depths to $10 \mathrm{~km}$.

For the temporal evolution of the geothermal regime, a commonly used approach is adopted with simplified assumptions for SCB (Green et al., 2009; Kerimov et al. 2010; Abdullaev et al., 2015). The supposed permanent subsidence of SCB allows to assume that paleotemperatures during sedimentation (MesozoicMiocene) did not essentially differ from modern ones, measured in wellbores at corresponding depths, and $t(H)$ dependences can be used as reference curves with appropriate recalculation of depth marks. The paleotemperatures of already deposited formations in earlier epochs (e.g., Mesozoic deposits in the period from Paleogene to Miocene) are estimated by progressive summation of temperature increments downwards from the reference point, taken as the modern temperature at the Productive Series base. These issues are comprehensively described by (Kerimov et al., 2010).

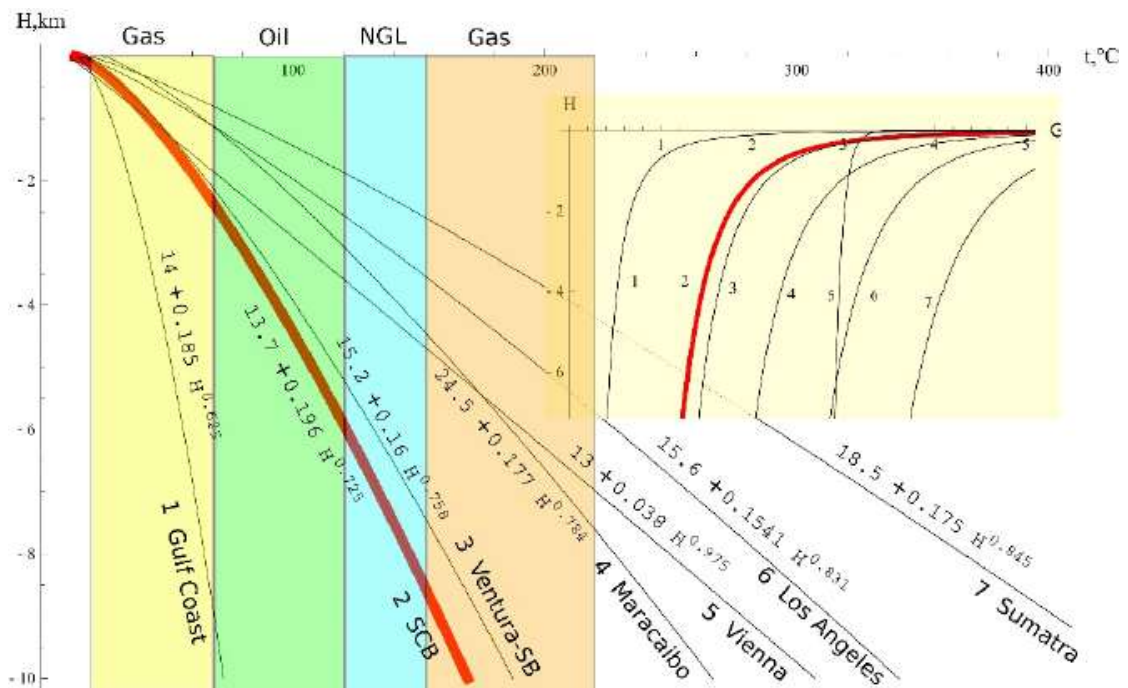

Fig. 3. Geothermal environments in major basins. SCB (No.2) is marked with a red line.

Color bars schematically outline generation windows for $\mathrm{HC}$ fractions. The inset shows thermal gradients (in ${ }^{\circ} \mathrm{C} / 100 \mathrm{~m}$ )

Other parameter inputs into the modeling algorithms include sedimentation and subsidence rates. They are obtained by backstripping analysis over ultradeep wellbores and outcrops on flanges (Kerimov et al., 2015) and were briefly described above. For a permanent subsidence of the basin with ultradeep (up to $25 \mathrm{~km}$ ) sedimentary deposits, a natural conjecture for modeling is the compensation of these two factors neglecting the contribution from other tectonic movements (subduction, folding etc).

As an indicator of thermal maturity, the vitrinite reflectance Ro is used. Hydrocarbon fractions are identified by conventional limits of temperature windows for oil, gas and condensate formation supported by wellbore data. The obvious simplification is that catagenetic transformations are the same across SCB and predominantly controlled by temperature. $\mathrm{HC}$ generation and migration modeling in PETROMOD is based on the kinetic schemes of kerogene decomposition with account for lithology, thickness and limiting saturation of the source rocks. The simulation of oil and gas generation was performed according to the first order kinetic scheme (Tissot et al., 1987; Burnham, 1989; Burnham, 2015) with a number of parallel reactions. This scheme is one of the two routines embedded in
PETROMOD. The maturity modeling in this work is performed according to (Sweeney and Burnham, 1990). Six maturity zones are defined and labeled by the maturity parameter: undermature (below $0,5 \%$ Ro), early oil generation (from 0,5 to $0,7 \%$ Ro), peak (middle) oil $(0,7-$ $1,0 \%$ Ro), late oil $(1,0-1,3 \%$ Ro), gas $(1,3-2,6 \%$ Ro $)$ and overmature (above $2,6 \%$ Ro). In the simulation of $\mathrm{HC}$ migration towards traps, pressure and lithology of rocks is taken into account. The accumulation modeling considered the properties of the overlying strata, and the presence of faults, conducting $\mathrm{HC}$ to the surface.

Results: Basin evolution and HC migration in SCB at a regional scale. The results of the computer simulation along the profile $\mathrm{C}_{-} \mathrm{C}^{\prime}$ in Fig. 1 are presented in Figs. 4 and 5 (SCB is on the left part of the figures, corresponding to SW edge of the profile). Fig. 4 outlines the basin evolution up to its present state, and hydrocarbon content of stratigraphic intervals, determined according to simplified assumptions, as described above. The stratigraphic arrangement for the present time moment (last panel in Fig. 4) is derived from the geological interpretation of the corresponding seismic profile, and constitutes the initial step for the lookback modeling. For clarity, we stripped lithology and tectonic related layers (faults etc) to 
avoid overcrowding of panels in Figures; this information can be retrieved from the next Fig. 5 .

In the Late Devonian several areas of the future basin (its south-western and northern edges) were filled with considerable sedimentary masses from the Early Devonian, already at the maturation stage, sufficient for $\mathrm{HC}$ generation. At the beginning of Triassic, the maturation process continued, and lower Devonian strata became overmature; Permian sediments were still beyond the maturity window.

At the beginning of Cretaceous, Jurassic reservoirs had already started to accumulate hydrocarbons. To that time, source rocks were Triassic sediments at a depth of $3 \mathrm{~km}$, and the main gas generation window was located at ca. $5 \mathrm{~km}$. Before the beginning of Paleogene, available hydrocarbons migrated towards surface without being retained within the formations because of caprocks lacking. Up to the Early Paleogene, traps had already been formed as anticline structures, and caprock structures appeared as well. Underlying reservoirs (Jurassic and Cretaceous) mostly accumulated liquid $\mathrm{HC}$ fractions. Note also the $17 \mathrm{~km}$ thick sedimentary cover at the southwestern margin of the depression to that time. However, Carboniferous-Permian rocks had already left the generation window, and became overmature.
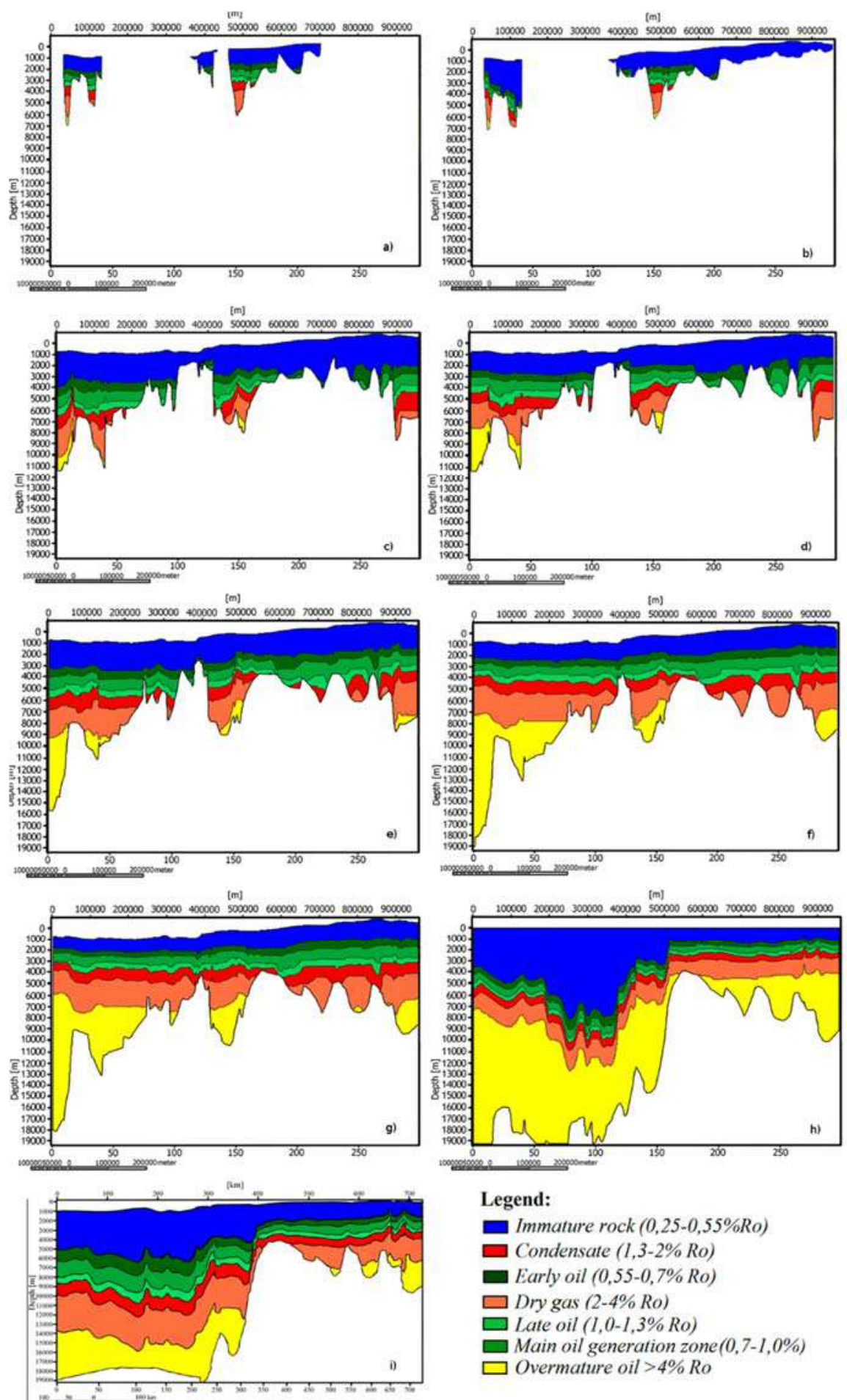

$$
\begin{aligned}
& \text { Legend: } \\
& \text { Immature rock }(0,25-0,55 \% \text { Ro }) \\
& \square \text { Condensate }(1,3-2 \% \text { Ro }) \\
& \text { Early oil }(0,55-0,7 \% \text { Ro }) \\
& \square \text { Dry gas }(2-4 \% \text { Ro }) \\
& \square \text { Late oil }(1,0-1,3 \% \text { Ro) } \\
& \square \text { Main oil generation zone }(0,7-1,0 \%) \\
& \square \text { Overmature oil }>4 \% \text { Ro }
\end{aligned}
$$

Fig. 4. HC generation models and basin evolution along C-C' profile from Devonian till present. Maturity stages are color marked. Snapshots for: a) Late Devonian; b) Late Permian; c) Early Triassic; d) Early Jurassic; e) Early Cretaceous; f) Early Paleogene;

g) Early Neogene; h) beginning of Late Neogene; i) present 
By the beginning of Early Neogene, the main oil generation zone was located at a depth of $2,5-3 \mathrm{~km}$, and the gas zone at 3,5-4 km. Till the beginning of the Late Neogene the basin is distinguished by an avalanche subsidence with deposition of up to $22 \mathrm{~km}$ thick sedimentary masses. This process is ongoing.

The SCB simulation results for the actual time moment (last panel in Fig. 4) indicate the oil and gas generation zone, stretching for 8-15 km with upper boundary at 5-7 km and lower boundary extending somewhat up to $18-20 \mathrm{~km}$ downwards (in the most subsided parts of the depression). Such localization of the generation window suggests that the fluid generation zone spans rocks with ages from Mesozoic till the beginning of Pliocene. The lower boundary of the gas generation window refers to Paleogene and Mesozoic sediments, and the upper boundary of the oil generation to Miocene. It is expected, that Mesozoic strata are characterized by the predominant generation of mature gas, and the whole spectrum of generated fluids can be responsible for the formations of Paleogene-Miocene.

The simulation results on short profiles $A$ and $B$ (Fig. 1) will be a subject of a more specialized contribution. The results for the eastern edges of these profiles, which enter SCB in the locations far from the regional C-C' profile, allow us to independently confirm certain trends, revealed for the "long" profile. Specifically, at the eastern margin of A profile the Oligocene (Lower Maykop) rocks were in the gas window during deposition of the Productive Series. At present, Upper Maykop rocks are located within the gas generation window. In contrast to the profile $A$, which stretches close to the Northern flange of the basin, the profile $B$ crosses the depression of Kura river, and its eastern edge runs into the most subsided parts of SCB close to its center. At present time, the main oil generating window at the eastern edge of this profile involves OligoceneMiocene rocks and is located at a depth of 3,5-5,5 km. The gas generation zone is located at a depth of $6-9 \mathrm{~km}$, spanning across Cretaceous and Upper Jurassic strata.

The simulation of the basin history backwards in time shows marked trends of separation and individualization of SCB compared to the Turan platform in the north (right part of Figs), which became emphasized in CretaceousPaleogene. The snapshot at the beginning of Late Neogene is a special moment of the basin history, since it corresponds to the beginning of the Pliocene Productive Series deposition. It is characterized by several extended layers of caprocks, generally of clayish lithology (Kalinsk (KaS) clay top, Nadkirmaky clay (NKG), clay top of the Fasila suite (SP) etc), which were deposited relatively recently and formed natural barriers for vertical $\mathrm{HC}$ migration from underlying horizons, e.g., from Maykop and Diatom suites. The availability of such regional wide caprocks at predominantly horizontal layered tectonic setting of the upper formations (a subordinate role of faults and other vertical migration channels) resulted in the essential contribution of the lateral $\mathrm{HC}$ migration in these layers. Results for the regional distribution of $\mathrm{HC}$ along $\mathrm{C}-\mathrm{C}^{\prime}$ profile are exemplified in Figure 5 for the present time moment, where oil (green color) and gas (red) areas and migration routes are well separated. For other simulation runs, reconstructed sections for the beginning of Late Neogene and other time moments were also considered as base.

As the migration models show, some hydrocarbons, migrated from source rocks during Neogene, could not form deposits due to the fact that by this time considerable regional seals had not been formed yet, so a part of the hydrocarbons had migrated upwards along fractures and dissipated. This process must be still ongoing, as the snapshot in Fig. 5 clearly indicates for the zones of deep penetrating fractures. Some of already formed deposits have been destroyed by high temperatures and pressures at subsurface during intensive basin subsidence in Cenozoic. The oil migration rates range from several to several hundreds kilometers per 1 million years. The formation time of the accumulated structures is from 1 to $100 \mathrm{MA}$. It is controlled by both migration rates and path lengths. Considerable thickness and volumes of sedimentary masses in the main generation window, intense tectonics and considerable geological time elapsed after the finishing of $\mathrm{HC}$ generation favor the migration and displacement of $\mathrm{HC}$ deposits upwards in the sedimentary cross-section from the deep zones of catagenetic generation. The principal element of the generation and accumulation scheme is the stepwise pulsation and injective mechanism of migration.

Case study: HC migration and accumulation in ACG structure. The giant ACG (Azeri-Chirag-Gyuneshli) oil field is an extended SE trending $100 \mathrm{~km}$ long structure associated with multiple dome-shaped risings in an anticline fold, forming a trap for hydrocarbons. On the regional profile, this is a short section at the "kink" of the profile line in its middle part (Fig. 1). ACG field has both oil and gas condensate deposits. The distribution of $\mathrm{HC}$ fractions over the Productive Series reservoirs is in apparent contradiction with the assumption of vertical migration mechanisms only. The upper part of PS (Balakhany and Fasila suites - see Fig. 2) contains oil, and the lower strata (Nadkirmaky, Podkirmaky and Kalinsk) are mostly filled with gas. In case of vertical migration, the cap rocks, which had let oil flows pass through, would have transmitted gas as well, so upper formations should be dominated by gas fractions, which is exactly the case of the nearby Bakhar field. To explain this inconsistency, a qualitative model for this deposit was designed based on the regional simulation and general scheme of conjectured $\mathrm{HC}$ migration. It combines both vertical and intralayer migration mechanisms. It is supposed, that generated hydrocarbons first migrate vertically through clayish strata until they meet a first laterally extended formation of permeable rocks. Then, $\mathrm{HC}$ distribute laterally over that layer towards the trap. Depending on the trap size and its sealing properties, $\mathrm{HC}$ would either fill up the trap and start spilling into the adjacent structures, or break the impermeable bed and flow into upper layers. As a result, upper and lower formations of the Productive Series are filled separately according to different mechanisms, that is with different relative contributions from lateral and vertical migration. So, the formation of the gas condensate layers at the bottom of the Series (Fig. 6, a) occurred through the predominately lateral mechanism by migration from a focus on the east through reservoirs of the lower suites (Podkirmaky, Kalinsk). The clay top of the Nadkirmaky suite (NKG) is an excellent regional seal rock. This focus (Maykop and Diatom rocks) is relatively sunken and fits partially the gas generation window; therefore, gas partially displaces oil in the lower formations of Productive Series in anticline traps (Fig. 6, a). Vice versa, oil prone "tops" of the Productive Series (Balakhany and Fasila suites) are formed through another route, via Absheron structures, located to the southwest (Fig. 6, b). Here, the seal rocks of NKG suite are less dense because of increased sedimentation rate (towards SCB center), so the anticline traps of Absheron host gas fraction, breaking the NKG suite and displacing oil to adjacent structures. Oil migrates laterally through Fasila and Balakhany suites (upper part of PS) and rises along strata in the north-eastern direction towards ACG traps. 


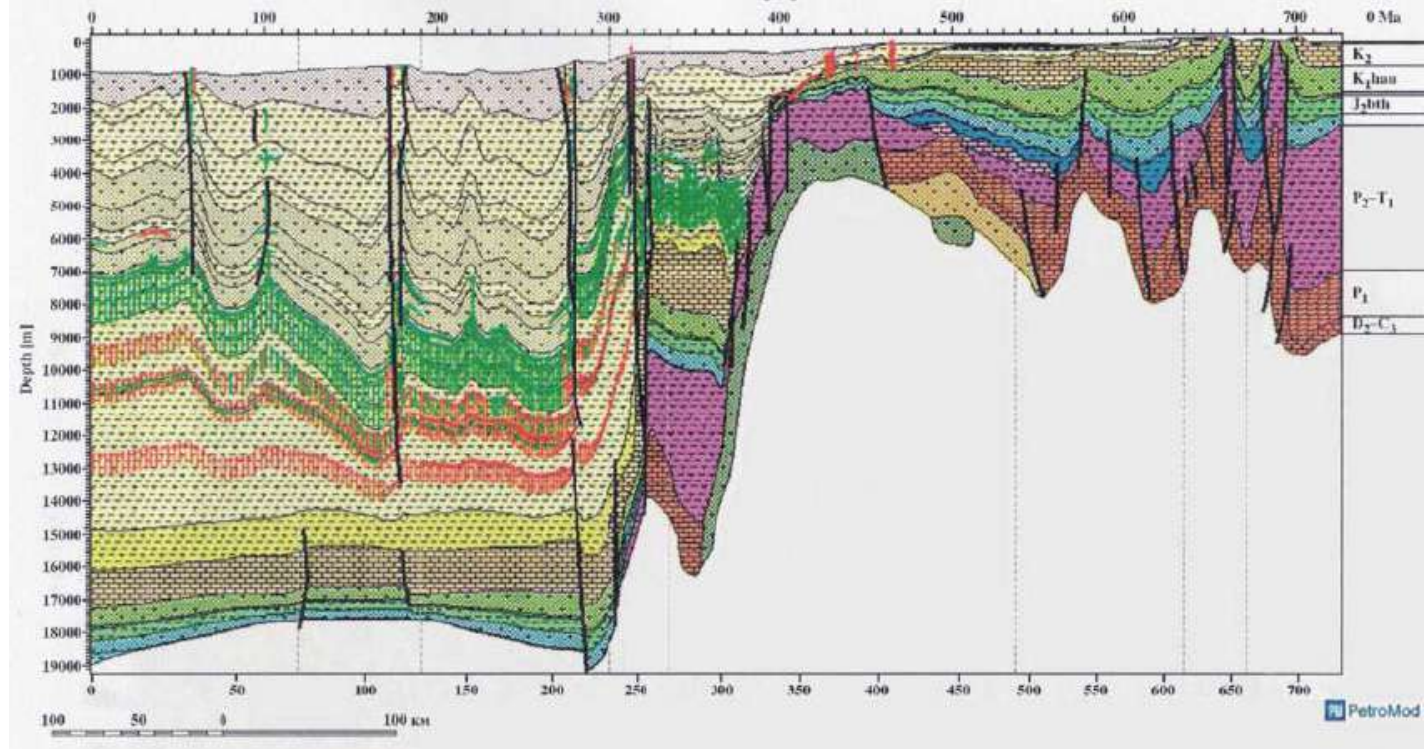

Fig. 5. Oil (green) and gas (red) migration model along the regional profile C-C'

Discussion. The key issue for the design of the $\mathrm{HC}$ distribution models in SCB and one of disputable questions is the basin opening time. Most authors agree on the point that the start of the basin formation is related to the rift opening in Mesozoic, during Cretaceous or Middle Jurassic (Zonenshain and Le Pichon, 1986), or at the boundary of $\mathrm{MZ}$ and $\mathrm{Pg}$ (Abrams et al., 1997). Some approaches directly postulate the rift formation event, e.g., in Middle Jurassic, as a starting point for simulations (Green et al., 2009; Abdullayev et al., 2015). Several authors consider the possibility of multi-stage basin opening (Golonka, 2007) with stage ages from early Mesozoic to Miocene. The models are also known, suggesting more early opening or formation according to pull-apart mechanism. So, it is assumed (see (Berberian, 1983) and references therein), that the basin can be a remnant of PaleoTethys, captured during Kimmerian convergence, so the crust age would reach Paleozoic or early Mesozoic. According to our results, a considerable sedimentary cover appeared in the SW and NE parts of the future SCB already in Devonian. These points correspond to Alborz trog and Greater Caucasus structure. On the one hand, this can be a consequence of an unjustified extrapolation of sedimentation data backwards in time. On the other hand, synthetic data on two wells near Alborz (see Fig. 5 in (Brunet et al., 2003), boreholes No. 5,6 ), one of which is located close to our profile, indicate at the start of sedimentation and subsidence of these structures in Devonian, thus agreeing with our results. The interpreted geological cross section by (Brunet et al., 2003) in the NW-SE direction also points at the existence of the Paleozoic crust near Alborz structures. At the same time, (Brunet et al., 2003) disprove the existence of a sedimentary cover with comparable thickness in the northern part of the depression, suggested by our results. These areas, according to (Brunet et al., 2003), are filled with Mesozoic volcanic sediments, therefore it is possible, that the extrapolation for these areas yielded an overestimated age without account of this Mesozoic volcanism.

Next, the depression itself opens approximately in Triassic, and the depth of the basin and the properties of organic matter are comparable to the results in the NE part of the profile (Middle Caspian depression). At the corresponding snapshot (Fig. 4, panel c)), the SW part of the basin close to Alborz structures already acquired the thickest sedimentary cover in the area. These results agree up to that point with models, dating the depression opening back to Mesozoic (Zonenshain and Le Pichon, 1986; Brunet et al., 2003; Green et al., 2009; Abdullayev et al., 2015), rather than to Upper Mesozoic-Paleogene (Abrams et al., 1997; Khain, 2005). The agreement of the timing results with mentioned well data on Alborz structures suggests their feasibility at least for the southern part of the depression.

The modeling states, that HC generation in Jurassic sediments in the northern part of the basin started in Early Cretaceous with gradual shift of the fluid generation foci towards its western part and central part of the Absheron peninsula. General trends of SCB evolution are confirmed by the recent detailed 3D simulations of the Northern part of SCB (Babayev and Gadiyev, 2006; Kerimov et al., 2015). In particular, for sediments of several time snapshots (Jurassic, Lower Cretaceous) in 2D modeling the tendency is marked of the decrease in maturity in the direction from most subsided central SCB areas towards north-east (Absheron rising in the center of the profile line). This is markedly seen on the corresponding 3D model graphs. This trend correlates with the spatial distribution of ${ }^{13} \mathrm{C}$ isotope enrichment: $\mathrm{HC}$ isotope composition becomes heavier in ${ }^{13} \mathrm{C}$ towards the most sunken parts of SCB (Guliyev et al., 2001 a; 2003). This general conclusion is justified by the ages of oil and condensate (Inan et al., 1997; Guliyev et al., $2001 \mathrm{a}, \mathrm{b}$ ). The oil ages on the western SCB flange vary in the range 94-175 MA, the ages of condensates - within 80-115 MA (Kerimov et al., 2010 and references therein). Geochemical studies of gases and organic matter in mud volcanoes, associated with Pliocene deposits, point at their deep provenance $(5-15 \mathrm{~km}$ for gases (Feyzullaev, 2012)) and profound reworking (Bonini et al., 2013). The need for essential vertical migration to adequately explain the $\mathrm{HC}$ composition from geochemical data is stressed by (Katz et al., 2000; Gürgey, 2003). According to (Katz et al., 2000), gas composition points at mixed biogenic and thermogenic $\mathrm{HC}$ provenance from source rocks below the Maykop suite. Multiple geochemical studies, especially earlier ones (Gürgey, 2003; Abrams et al., 1997 and references therein), adhere to more conservative concepts, claiming the predominant $\mathrm{HC}$ formation in Ol-Mi Maykop and Diatom sediments with variety of opinions as to the role of vertical migration. Finally, geochemical evidences of $\mathrm{HC}$ formation mostly in nearshore and deltaic environments (for example, by the fraction of ${ }^{13} \mathrm{C}$ content in aromatic vs alkane hydrocarbons - (Guliyev et al., 2001b; Guliyev et al., 2003) argue in favor of the epigeneticity, since Pliocene reservoirs are known to form in the environments of closed limnetic fresh water pools. 


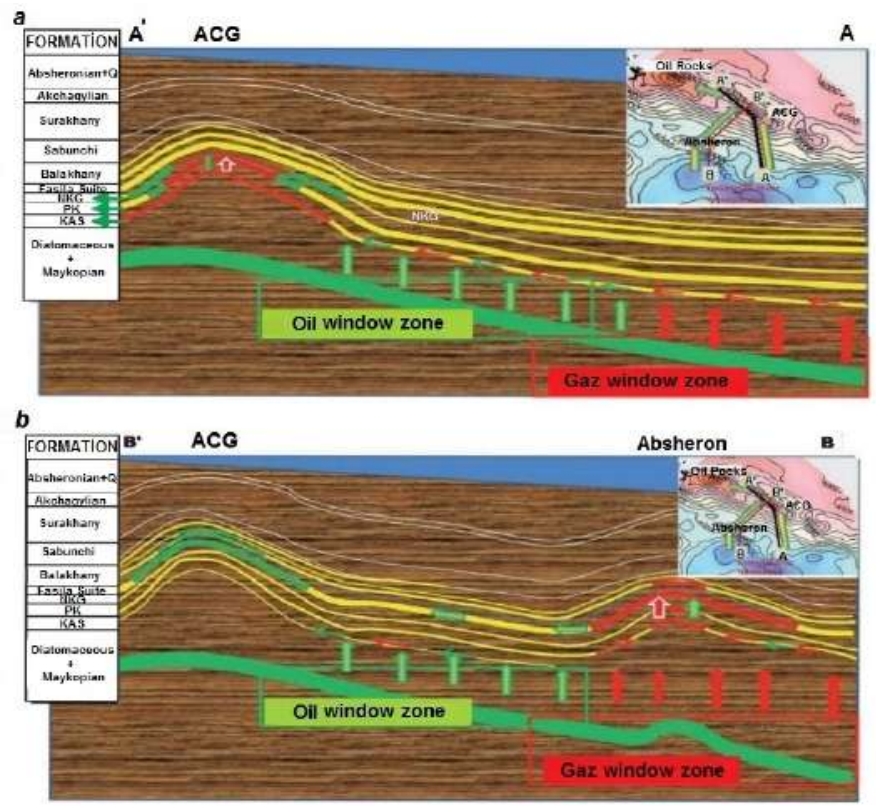

Fig. 6. Hydrocarbon migration model near ACG oil field (modified from (Guliyev et al., 2016)).

a - NW-SE profile (a-a'); formation of bottom (gas condensate) part of the Productive Series, eastern flow; b - NE-SW profile (b-b'); formation of top (oil prone) part - western flow

Geothermal data and stratigraphy show, that in most SCB areas Mesozoic rocks (thickness 4,5-11 km, top and bottom temperature $167-424^{\circ} \mathrm{C}$ ) now generate high temperature carbon dioxide and Nitrogen; PaleogeneMiocene (thickness $2,5-2,0 \mathrm{~km}, 76-237^{\circ} \mathrm{C}$ ) are donors of oil, wet gas and condensate and partially - of late catagenetic methane. Pliocene-Holocene rocks generate early catagenetic methane and minor amounts of early generation oils (Guliyev et al., 2001, a; Kerimov et al., 2010; Feyzullayev, 2013, b). The results on short profiles A, B also fall in this general pattern, indicating that in the most subsided areas (continuation of $B$ profile) the modern gas generating zone is located within Mesozoic sediments (depths about $10 \mathrm{~km}$ ). As simulation suggests, and wellbore data at moderate depths confirm, the oil and gas generation zone in SCB can reach the depths of $8-10 \mathrm{~km}$, the zone of condensate and wet gas - up to $12-14 \mathrm{~km}$, that is $\mathrm{HC}$ generation processes are active mostly in sediments underlying the Productive Series. This conclusion supports the predominantly secondary nature of $\mathrm{HC}$ saturation of $\mathrm{PS}$, thus the results testify in favor of the allochtonous $\mathrm{HC}$ concept (Inan et al., 1997; Bonini et al., 2013; Feyzullaev, 2013, a; Guliyev and Bagirov, 2016). An additional argument for this mechanism is the anomalous formation pressure in the Pliocene reservoirs. (Guliyev and Bagirov, 2016) conjecture, that its principal cause are injections of high pressure fluids from the underlying strata within local risings and anticlines (cf. case study for the ACG field). The estimates for $\mathrm{HC}$ potential depths were performed without taking into account anomalous formation pressures. It is commonly assumed, that overpressure plays merely a subordinate role in $\mathrm{HC}$ transformation compared to temperature and time, and numerous overpressure zones in SCB (Feyzullayev, 2013, a) control first of all the HC flow patterns. However, the general impact of the overpressure on $\mathrm{HC}$ maturation is its retardation due to the formation of a closed thermodynamical system with obstructed migration outwards (see (Feyzullayev, 2013, b) and references therein). This is a favorable factor for the preservation of the $\mathrm{HC}$ generation ability at ultra high depths. This allows to expect a further extension of the oil and gas windows compared to the model. Refinements of model results should embed the pressure factor into the kinetics simulation. The HC distribution modeling shows, that both vertical and lateral migration patterns matter. The balance of migration types varies by horizons and areas and is determined by the rigidity and rupture strength of the seal rock and the availability of fractures, cracks and loosened crust areas nearby. These latter can be revealed by the concentration of mud volcanoes in this area (Huseynov and Guliyev, 2004; Bonini et al., 2013). On the one hand, they are additional prospecting indicators for verification of $\mathrm{HC}$ migration and accumulation models. On the other hand, they act as natural ultradeep wells providing information on the deep structure. For example, intense mud volcanism in SCB is mostly related to the lower hydrocarbon layer; vice versa, many oil deposits show no genetic relations with $\mathrm{HC}$ of the upper Productive Series (Aliyev and Aliyev, 2011). The ACG field, like other major fields (Shah-Deniz etc), is a typical example of a structure, associated with mud volcanism. Such an association can be an additional argument for the allochtonous hypothesis of migration.

Conclusions. The principal result of the work is the confirmation of systematic character of lateral and vertical $\mathrm{HC}$ migration patterns over the cross section of SCB, and of the regular evolution of $\mathrm{HC}$ formation foci in time, generally towards the central zone of South Caspian. The modeling results suggest the expansion of the limits of the hydrocarbon potential downwards to depths to $\sim 12 \mathrm{~km}$. Prospecting works in the future should be designed taking into account this observation.

The conjectured opening time of SCB is Triassic. However, comparison with synthetic wellbore data and cross sections indicates possible overestimation of structures age in the northern part of the basin, qualitatively agreeing with data for its southern part. To improve the paleoreconstruction, it is necessary to refine the models of paleotemperature and sedimentation/ subsidence rate change, especially for the northern flange of the basin (Absheron depression) taking into account Mesozoic volcanism in this region.

The correlation of the modeling results with geochemical ages, provenance depth and reworking degree for oils, gas and condensate confirms their epigenetic character in the hosting Pliocene-Holocene and Paleogene-Miocene series, and, reciprocally, their qualitative coeval identity and 
physico-chemical correspondence to the thermobaric conditions, characteristic of modern occurrence of the underlying Mesozoic strata. The principal source rock for low grade hydrocarbons (gases) are Mesozoic zones; for high grade hydrocarbons (oil and condensate) - Paleogene and Miocene sediments with only subordinate participation of the lower formations of the Productive Series. The modeling also supports geochemical data on the decrease of $\mathrm{HC}$ ages from edges towards the center of depression.

Since HC migration over the area is epigenetic with dominant vertical flows, structures to be discovered in the future at ultra high depths in Mesozoic-Cenozoic sedimentary cover will inherently have giant sizes and share similar migration patterns. Thermobaric conditions suggest, that source rocks for those formations are located even deeper, and HC migration from sources should be initially vertical, then continue laterally. This is already confirmed for depths to $7000 \mathrm{~m}$, so similar processes are to be expected at $8-9 \mathrm{~km}$. The poroperm properties of rocks at such depths can allow accumulation of commercially interesting amounts of $\mathrm{HC}$, only if such structures have giant sizes, similar to Shah-Deniz, ACG, Neft Dashlary, Kyapaz fields and so on. At smaller scale structures these phases are prohibited, since they can not preserve the necessary poroperm properties of rocks due to high lithostatic pressure.

The HC hosting capacity of SCB at depths down to $12 \mathrm{~km}$ or more suggests the need for future research to reveal factors, controlling the accumulation of commercial deposits. The investigations should aim at the identification of structural and tectonic patterns, favorable for deposit formation, modeling of petrophycs of reservoir rocks beyond $6 \mathrm{~km}$, and at recovering the geochronological scale for oil and gas generation, migration and accumulation conditions for discovered objects (prospective oil and gas fields). To refine the lower boundary of the $\mathrm{HC}$ potential, it is necessary to apply modern simulation schemes, taking into account the overpressure factor in $\mathrm{HC}$ generation. Of special interest are mechanisms of vertical migration of heavy hydrocarbons (oil fraction) into subsurface horizons, the composition of C8 $\mathrm{C} 10$ and aromatic fractures. One of the unsolved challenges is the paragenetic relation of $\mathrm{HC}$ generation foci with mud volcanoes and their ejecta composition. The study of mud volcanism in its relation to $\mathrm{HC}$ zones will give additional reference points for the refinement of local migration models. Geochemical studies should be oriented at the relation between $\mathrm{HC}$ content in the explored fields and their source rocks, to adjust and refine the hydrocarbon model of the South Caspian Basin.

\section{Список використаних джерел / References}

Abdullayev, N A Kadirov, F. Guliyev, IS (2015) Subsidence history and basin-fill evolution in the South Caspian Basin from geophysical mapping, flexural backstripping, forward lithospheric modelling and gravity modelling. Geol Soc Spec Publ., 427(27). doi: 10.1144/SP427.5.

Abrams, M.A. Narimanov, A.A. (1997). Geochemical evaluation of hydrocarbons and their potential sources in the western South Caspian depression, Republic of Azerbaijan. Mar. Petrol Geol., 14(4), 451-468. doi 10.1016/S0264-8172(97)00011-1.

Aliyev, A.I., Aliyev, E.A. (2011). Deep oil potential. Baku, Azerbaijan: Nafta Press.

Artyushkov, E.V. (2007). Formation of the superdeep South Caspian basin: subsidence driven by phase change in continental crust. Russian Geology and Geophysics, 48(12), 1002-1014. doi: 10.1016/j.rgg.2007.11.007.

Babayev, D.Kh., Gadjiyev, A.N. (2006). Deep structure and hydrocarbon potential of the Caspian Sea basin. Baku, Azerbaijan: Nafta Press. [in Russian with English abstract]

Berberian, M. (1983). The southern Caspian: a compressional depression floored by a trapped, modified oceanic crust. Can J. Earth Sci., 20, 163-183.

Bonini, M., Tassi, F., Feyzullayev, A.A., Aliyev, C.S., Capecchiacci, F., Minissale, A. (2013). Deep gases discharged from mud volcanoes of Azerbaijan: New geochemical evidence. Mar. Petrol Geol., 43, 450-463. doi:10.1016/j.marpetgeo.2012.12.003.

Brunet, M.F., Korotaev, M., Ershov, A.V., Nikishin, A.M. (2003). The South Caspian basin: a review of its evolution from subsidence modelling. In: Brunet, M-F. and Cloetingh, S. (Eds.). Integrated Peri-Tethyan basin studies
(Peri-Tethys Programme). Sediment Geol, 156, 119-148. doi: 10.1016/S0037-0738(02)00285-3.

Burnham, A.K. (1989). A simple kinetic model of petroleum formation and cracking. Technical Report. Lawrence Livermore National Lab., Livermore. Burnham, A.K. (2015). A Simple Kinetic Model of Oil Generation, Vaporization, Coking, and Cracking. Energy Fuels, 29(11), 7156-7167. doi:10.1021/acs.energyfuels.5b02026.

Buryakovsky, L., Chilingar, G.V., Rieke, H.H., Shin, S. (2012). Fundamentals of the Petrophysics of Oil and Gas Reservoirs. Wiley. doi: 10.1002/9781118472750.

Davies, R.J., Stewart, S.A. (2005). Emplacement of giant mud volcanoes in the South Caspian Basin: three-dimensional seismic reflection imaging of root zones. Journal of the Geological Society, 162 (1), 1-4. doi: 10.1144/0016764904-082.

Feyzullayev, A.A. (2012), Mud volcanoes in the South Caspian basin: Nature and estimated depth of its products. Natural Science, 4, 445-453. doi: 10.4236/ns.2012.47060

Feyzullayev, A.A. (2013a). Migration Pathways of Hydracarbons in SouthCaspian Basin. J. Geol. Geosci., 2, 127. doi:10.4172/2329-6755.1000127.

Feyzullayev, A.A. (2013b). The role of pressure in thermocatalytic processes in the sedimentary complex of the South Caspian basin. Russian Geology and Geophysics, 54 (2), 200- 205. doi:10.1016/j.rgg.2013.01.006.

Gahramanov, G.N., Babayev, M.S., Shpyrko, S.G., Mukhtarova, Kh.Z. (2019). Geothermal conditions of hydrocarbon prospects of Meso-Cenozoic formations in South Caspian Basin. Geophysical Journal, 41(5), 222-234. doi: 10.24028/gzh.0203-3100.v41i5.2019.183638 [in Russian with English abstract]

Glumov, I.F. et al. (Editors) (2004). Regional geology and oil and gas content of Caspian Sea. Moscow, Russia: Nedra [in Russian with English abstract]

Golonka, J. (2007). Geodynamic evolution of the South Caspian Basin. In: Yilmaz, P.O. and Isaksen, G.H. (Eds.) Oil and gas of the Greater Caspian area. AAPG Studies in Geology, 55, 17-41. doi: 10.1306/E4FD36E9-173211D7-8645000102C1865D

Green, T., Abdullayev, N., Hossack, J., Riley, G., Roberts, A . (2009). Sedimentation and subsidence in the South Caspian Basin, Azerbaijan. In: Brunet, M.-F., Wilmsen, M. and Granath, J. W. (Eds.) South Caspian to Central Iran Basins. Geol. Soc. Spec. Publ., 312, 241-260, doi:10.1144/SP312.12.

Guliyev, I.S., Feyzullayev, A.A., Huseynov, D.A. (2001a). Carbon isotopic composition of the hydrocarbon fluids of the South Caspian megadepression. Geochemistry International, 39(3), 237-243.

Guliyev, I.S., Feizulayev, A.A., Huseynov, D.A. (2001b). Isotope geochemistry of oils from fields and mud volcanoes in the South Caspian Basin, Azerbaijan. Petroleum Geoscience, 7, 201-209. doi: 10.1144/petgeo.7.2.201

Guliyev, I.S., Mamedov, P.Z., Feyzullayev, A.A. et al. (2003). Hydrocarbon systems of the South Caspian Basin. Baku, Azerbaijan: Nafta-Press.

Guliyev, I.S., Fedorov, D.L., Kulakov, S.I. (2009). Hydrocarbon potential of the Caspian region. Baku, Azerbaijan: Nafta-Press

Guliyev, I.S., Bagirov, E.S. (2016). Role of seal rocks in the formation of hydrocarbon deposits in South Caspian basin and prognosis of accumulations in the offshore Absheron section (part II). Azerbaijan Oil Industry Journal, 7-8, 3-10. [in Russian with English abstract]

Guliyev, I.S., Kerimov, V.Yu., Osipov, A.V., Mustaev, R.N. (2017). Generation and accumulation of hydrocarbons at great depths under the Earth's Crust. SOCAR Proceedings, 1, 004-016. [in Russian with English abstract]

Gürgey, K. (2003). Correlation, alteration, and origin of hydrocarbons in the GCA, Bahar, and Gum Adasi fields, western South Caspian Basin: geochemical and multivariate statistical assessments. Mar. Petrol. Geol., 20(10), 1119-1139. doi:10.1016/j.marpetgeo.2003.10.002

Huseynov, D., Guliyev, I. (2004). Mud volcanic natural phenomena in the South Caspian Basin: geology, fluid dynamics and environmental impact. Environmental Geology, 46, 1012-1023. doi:10.1007/s00254-004-1088-y.

Inan, S., Yalcin, N., Guliev, I., Kuliev, K., Feizullaev, A. (1997). Deep petroleum occurrences in the Lower Kura Depression, South Caspian Basin, Azerbaijan: an organic geochemical and basin modelling study. Mar. Petrol Geol., 14(7/8), 731-762. doi: 10.1016/S0264-8172(97)00058-5.

Javanshir, R., Riley, G., Duppenbecker, S., Abdullayev, N. (2015). Validation of lateral fluid flow in an overpressured sand-shale sequence during development of Azeri-Chirag-Gunashli oil field and Shah Deniz gas field: South Caspian Basin, Azerbaijan. Mar. Petrol Geol., 59, 593-610. doi: 10.1016/j.marpetgeo.2014.07.019

Katz, K.J., Richards, D., Long, D., Lawrence, W. (2000). A new look at the components of the petroleum system of the South Caspian Basin. Journal of Petroleum Science and Engineering, 28(4), 161-182. doi: 10.1016/S09204105(00)00076-0.

Kauerauf, A., Hantschel, T. (2009). Fundamentals of Basin and Petroleum Systems Modeling. Berlin-Heidelberg: Springer. doi:10.1007/978-3-540-72318-9. Kerimov, V.Yu., Rachinskiy, M.Z., Kolushkina, O.V. (2010). Conditions of oil and gas generation in South-Caspian basin. Proceedings of Gubkin Russian State University of Oil and Gas, 2/259, 29-38. [in Russian with English abstract]

Kerimov, V.Yu et al. (Eds.). (2015). Prognosing hydrocarbon potential in regions of complicated deep structure. Moscow, Russia: Nedra. ISBN: 9785-8365-0430-4.

Khain, V.E. (2001). Tectonics of continents and oceans (year 2000). Moscow: Nauchnyj Mir [in Russian with English abstract]

Khain, V.E. (2005). The problem of the origin and the age of the South Caspian Basin and its possible solutions. Geotectonics, 39(1), 34-38. 
Khain, V.E. et al. (Eds.). (2009). Tectonics of the southern margins of EastEuropean platform (Explanatory note to the tectonic map of Black Sea and Caspian region, Scale 1:2 500 000), Krasnodar [in Russian with English abstract] Klett, T.R., Schenk, C.J., Charpentier, R.R., Gautier, D.L., Brownfield, M.E., Pitman, J.K., Cook, T.A., Tennyson, M.E. (2010). Assessment of undiscovered oil and gas resources of the North Caspian Basin, Middle Caspian Basin, North Ustyurt Basin, and South Caspian Basin Provinces, Caspian Sea Area. U.S. Geological Survey Fact Sheet 2010-3094, 4 p.

Makhous, M., Galushkin, Yu.I. (2005). Basin analysis and modeling of the burial, thermal and maturation histories in sedimentary basins. Paris: Editions Technip. ISBN 2-7108-0846-3.

Mustayev, R.N. (2013). Conditions for formation and hydrocarbon potential prognosis at the western flange of the South Caspian depression. Extended abstract ... Doctor's thesis in geology and mineralogy. Moscow. [in Russian with English abstract]

Piip, V.B., Rodnikov, A.G. Buvaev, N.A. (2012). The Deep Structure of the Lithosphere along the Caucasus-South Caspian Basin-Apsheron ThresholdMiddle-Caspian Basin-Turan Plate Seismic Profile. Moscow University Geology Bulletin, 67(5), 314-319. [in Russian with English abstract]

Rachinskiy, M.Z., Kerimov, V.Yu. (2015). Fluid Dynamics of Oil and Gas Reservoirs. Scrivener Publishing LLC. doi: 10.1002/9781118999004.

Smith-Rouch, L.S. (2006). Oligocene-Miocene Maykop/Diatom Total Petroleum System of the South Caspian Basin Province, Azerbaijan, Iran, and Turkmenistan. U.S. Geological Survey Bulletin, 2201-I, 1-27.
Sweeney, J., Burnham, A. (1990). Evaluation of a Simple Model of Vitrinite Reflectance Based on Chemical Kinetics (1). Am. Assoc. Petr. Geol. B. 74(10), 1559- 1570

Tagiyev, M.F., Nadirov, R.S., Bagirov, E.B., Lerche, I. (1997). Geohistory, thermal history and hydrocarbon generation history of the north-west South Caspian Basin. Mar. Petrol Geol., 14(4), 363-382. doi: 10.1016/S02648172(96)00053-0.

Tissot, B.P., Pelet, R., Ungerer, P. (1987). Thermal history of sedimentary basins, maturity indices and kinetics of oil and gas generation. Am. Assoc. Petr. Geol. B., 71, $1445-1466$.

Vincent, S.J., Davies, C.E., Richards, K., Aliyeva, E. (2010). Contrasting Pliocene fluvial depositional systems within the rapidly subsiding South Caspian Basin; a case study of the palaeo-Volga and palaeo-Kura river systems in the Surakhany Suite, Upper Productive Series, onshore Azerbaijan. Mar. Petrol Geol., 27(10), 2079-2106. doi: 10.1016/j.marpetgeo.2010.09.007.

Welte, D., Hantschel, T., Wygrala, B., Weissenburger, K., Carruthers, D. (2000). Aspects of petroleum migration modelling. J. Geochem. Explor., 69, 711 - 714. doi:10.1016/S0375-6742(00)00105-9

Yusifov, M., Rabinowitz, P.D. (2004). Classification of mud volcanoes in the South Caspian Basin, offshore Azerbaijan. Mar. Petrol Geol., 21(8), 965975. doi:10.1016/j.marpetgeo.2004.06.002.

Zonenshain, L.P., Le Pichon, X. (1986). Deep basins of the Black Sea and Caspian Sea as remnants of Mesozoic back-arc basins. Tectonophysics, 123(1), 181-211. doi: 10.1016/0040-1951(86)90197-6.

Надійшла до редколегії 29.09.19

К. Каграманов, канд. геол. наук,

E-mail: gngahramanov@gmail.com,

Державна Нафтова Компанія Азербайджанської Республіки (SOCAR), Баку, Азербайджан;

М. Бабаєв, канд. геол. наук,

E-mail: m.s.babayev@mail.ru;

Азербайджанський Державний університет нафти та промисловості, Баку, Азербайджан;

С. Шпирко, канд. фріз.-мат. наук,

E-mail: sshpyrko@gmail.com,

Відділення морської геології НАН України, Київ, Україна;

Х. Мухтарова, канд. геол. наук,

E-mail: mukhtarova.khuraman@mail.ru,

Азербайджанський Державний університет нафти та промисловості, Баку, Азербайджан

\section{МОДЕЛЮВАННЯ ІСТОРІЇ ЗАНУРЕННЯ ТА МІГРАЦІЇ ВУГЛЕВОДНІВ У ПІВДЕННО-КАСПІЙСЬКІЙ ЗАПАДИНІ}

Вивчаються механізми міграції та просторовий розподіл вуглеводневих скупчень вздовж регіонального сейсмопрофілю південнозахідного простягання через Південно-Каспійську западину довжиною близько 1000 км. Виконано ретроспективне двовимірне геологічне моделювання занурення басейну та історії накопичення осадів з урахуванням супровідних термічних і катагенетичних перетворень органічної речовини, а також наступної міграції та акумуляції вуглеводнів.

Початок розкриття басейну з накопиченням істотної маси відкладів можна віднести до середнього мезозою (тріас або юра), а насичені вуглеводнями горизонти нині можуть бути на глибинах до 12 км. Насичення вуглеводнями пліоценової Продуктивної товщі має епігенетичний (алохтонний) характер, що також підтверджується даними геохімічних досліджень грязьових вулканів та іншими фактами. Геохімічний вік, глибинність і ступінь переробки вуглеводнів указують на джерела їхньої генерації у мезозойських (газ) і палеоген-міоценових комплексах (нафота) за підпорядкованою участю нижніх горизонтів пліоценової Продуктивної товщі. Переважною формою переміщення природних флюїдів $\epsilon$ субвертикальна ін'єкційна міграція між ярусами пульсаційного характеру, причому для руху фрлюїди використовують площини розривів, зони тріщинуватості та розущільнення, контакти діапірів, канали грязьових вулканів, структурні та фаціальні незгідності тощо. Це дозволяє розраховувати на акумуляцію вуглеводнів промислового масштабу на надвисоких глибинах за умови наявності структур великого розміру, зіставних із відкритими гігантськими родовищами (Шах-Деніз, Азері-Чираг-Гюнешлі).

Ключові слова: міграція вуглеводнів, моделювання осадового басейна, ретроспективне моделювання, нафтогазоносність надвисокUх глибин, PETROMOD.

К. Каграманов, канд. геол. наук,

E-mail: gngahramanov@gmail.com,

Государственная Нефтяная Компания Азербайджанской Республики (SOCAR), Баку, Азербайджан;

М. Бабаев, канд. геол. наук,

E-mail: m.s.babayev@mail.ru,

Азербайджанский Государственный университет нефти и промышленности, Баку, Азербайджан;

С. Шпырко, канд. физ.-мат. наук,

E-mail: sshpyrko@gmail.com,

Отделение морской геологии НАН Украины, Киев, Украина;

Х. Мухтарова, канд. геол. наук,

E-mail: mukhtarova.khuraman@mail.ru,

Азербайджанский Государственный университет нефти и промышленности, Баку, Азербайджан

\section{МОДЕЛИРОВАНИЕ ИСТОРИИ ПОГРУЖЕНИЯ И МИГРАЦИИ УГЛЕВОДОРОДОВ В ЮЖНО-КАСПИЙСКОЙ ВПАДИНЕ}

Изучаются механизмы миграции и пространственное распределение углеводородных скоплений вдоль регионального сейсмопрофиля юго-западного простирания через Южно-Каспийскую впадину длиной около 1000 км. Выполнено ретроспективное двумерное геологическое моделирование погружения бассейна и истории его осадкозаполнения с учетом сопутствующих термических и катагенетических преобразований органического вещества, а также последующей миграции и аккумуляции углеводородов.

Начало раскрытия бассейна с накоплением значительной массы отложений можно отнести к среднему мезозою (триас или юра), а углеводородонасыщенные горизонты в настоящее время могут находиться на глубинах до 12 км. Насыщение углеводородами плиоценовой Продуктивной толщи носит эпигенетический (аллохтонный) характер, что также подтверждается данными геохимических исследований грязевых вулканов и другими фактами. Геохимический возраст, глубинность и степень переработки углеводородов указывают на источники их генерации в мезозойских (газ) и в палеоген-миоценовых комплексах (нефть) с подчиненным участием нижних горизонтов плиоценовой Продуктивной толщи. При перемещении флюидов преобладает субвертикальная инъекционная миграция между ярусами, носящая пульсационный характер и использующая для движения плоскости разрывов, зоны трещиноватости и разуплотнения, контакты диапиров, каналы грязевых вулканов, структурные и фациальные несогласия. Это позволяет рассчитывать на аккумуляцию УВ промышленного масштаба на сверхвысоких глубинах при условии наличия структур большого размера, сопоставимых с открытыми крупными месторождениями (Шах-Дениз, Азери-Чираг-Гюнешли).

Ключевые слова: миграция углеводородов, моделирование осадочного бассейна, ретроспективное моделирование, нефтегазоносность сверхвысоких глубин, PETROMOD. 